\title{
Myasthenia Gravis following Coxsackie Encephalitis
}

\author{
Thanaviratananich $\mathrm{S}^{* 1,2}$ and Katirji $\mathrm{B}^{1}$ \\ ${ }^{1}$ Neurological Institute, University Hospitals Cleveland Medical Center, Case Western Reserve University, Cleveland, Ohio, United \\ States \\ ${ }^{2}$ Department of Neurology, University of Michigan, Ann Arbor, Michigan, United States
}

*Corresponding author: Thanaviratananich S, Neurological Institute, University Hospitals Cleveland Medical Center, Case Western Reserve University, Cleveland, Ohio, United States, Tel: (734) 730-5058, E-mail: thanavir@ gmail.com

Citation: Thanaviratananich S, Katirji B (2017) Myasthenia Gravis following Coxsackie Encephalitis. SAJ Case Rep 4: 304

Article history: Received: 13 July 2017, Accepted: 29 August 2017, Published: 31 August 2017

\begin{abstract}
Background: Myasthenia gravis (MG) is a common autoimmune neuromuscular disorder. There is scarce literature on preceding infection leading to MG. We present a case of MG developed after coxsackie virus encephalitis.

Case description: A 62 year-old man who initially presented with acute alteration of mental status. Cerebrospinal fluid (CSF) analysis revealed a mild pleocytosis ( 42 white cells/uL) with lymphocytic predominance. CSF coxsackie virus A09, B2, and B5 antibodies were high $(1: 100,1: 32,1: 64$ respectively). He was diagnosed with coxsackie encephalitis and recovered in two months. Five months later, he presented with a 3-week history of diplopia, ptosis, dysphagia, and hoarseness. Acetylcholine receptor binding, blocking, and modulating antibodies were all elevated. Seropositive MG responded well to a combination of oral prednisone and pyridostigmine.
\end{abstract}

Conclusion: MG developed several months after coxsackie encephalitis. Given the temporal relationship, MG is possibly due to coxsackie virus triggering host autoimmunity.

Keywords: Myasthenia gravis; Coxsackie encephalitis

\section{Introduction}

Triggers of autoimmunity have included infections, vaccination, trauma and cancer [1-3]. In the majority of autoimmune disorders, a definite causation is unknown. Autoimmune neurological disorders may follow infectious diseases such as with Guillian-Barre syndrome, acute disseminated encephalomyelitis and neuralgic amyotrophy [4-6]. Cases of myasthenia gravis following West Nile encephalitis were recently reported [7]. We present a case of myasthenia gravis which developed five months after coxsackie encephalitis. We also review the literature on neurological autoimmune disorders occurring after encephalitis.

\section{Case Description}

A 62 year-old man, with no significant past medical history, was transferred to our hospital with changes in mental status for 3 weeks prior. After doing yard work, he felt later that day ill and developed rashes, which was treated with diphenhydramine and prednisone at a local urgent care. Next day, he became confused and behaved strangely. Three days later, he was taken an emergency room at a local hospital and was evaluated by psychiatrist. Three days later, he returned to the hospital and was admitted for deterioration of his confusion. He was agitated and received ziprasidone. He was afebrile but complete blood count showed leukocytosis (11,000 white cell counts/ $\mu \mathrm{L}$, with $3 \%$ bands). Computed tomography (CT) and magnetic resonance imaging (MRI) of the brain with contrast showed a small remote frontal infarct, otherwise unremarkable. Cerebrospinal fluid (CSF) analysis revealed 42 white cells/ $\mu \mathrm{L}$ (95\% lymphocytes and 5\% monocytes), with mildly elevated protein of $67 \mathrm{mg} / \mathrm{dL}$ and normal glucose. Due to suspicion of Herpes Simplex Virus (HSV) infection, acyclovir was started, which was later stopped after CSF HSV 1,2 
polymerase chain reaction (PCR) was negative. CSF Cytomegalovirus (CMV) PCR, Venereal Disease Research Laboratory test (VDRL), and bacterial cultures were all negative.

Examinations on admission to our hospital showed that he was febrile, somnolent, made some incomprehensible noises, and did not follow commands. A 14-hour video electroencephalogram (EEG) showed diffuse encephalopathy without epileptiform activities. Repeat CSF study revealed pleocytosis (17 white cells/ $\mu \mathrm{L}$ with $94 \%$ lymphocytes), no red blood cells, normal glucose and protein. Encephalitis panels including HSV-1,2 PCR, VDRL, lyme antibody, mycoplasma antibody, West Nile viral titers, La Crosse viral titers, Eastern/Western Equine viral titers and St Louis viral titers were negative. However, CSF showed high Coxsackievirus A09, B2, and B5 antibodies (1:100, 1:32, 1:64 respectively). The diagnosis of Coxsackie encephalitis was made and he was treated supportively. During his admission, his mental status improved. On the day of discharge after 24 days hospitalization, he became much more awake and oriented to self and place, and able to follow commands and answer questions. His speech was only slightly dysarthric. He gained full recovery approximately 2 months after discharge.

Five months after discharge, he presented with a 3-week history of generalized weakness, diplopia, ptosis, dysphagia, and hoarseness. Examinations revealed proximal muscles weakness without ptosis, or dysarthria on exams. Acetylcholine (Ach) receptor binding, blocking, and modulating antibodies were 63.5nmol/L (normal, $<0.4 \mathrm{nmol} / \mathrm{L}$ ), $71 \%$ (normal, $<26 \%$ ), and $74 \%$ (normal, $<45 \%$ ) respectively, consistent with the diagnosis of seropositive MG. Computed tomography of the chest did not reveal any thymic masses. He was started on oral pyridostigmine and prednisone with improvement in his symptoms. On one-month follow-up, he regained a full strength and had no signs of fatigability. He was maintained on prednisone $20 \mathrm{mg}$ daily and pyridostigmine $60 \mathrm{mg}$ every 3 hours when awake.

\section{Discussion}

Coxsackievirus is a non-enveloped ribonucleic acid (RNA) virus, which belongs to a genus Enterovirus. It is in the same genus as poliovirus, echovirus, and enterovirus. There two major groups of coxsackievirus, group A and B, are transmitted via the fecal-oral route. Infected patients are commonly asymptomatic or manifest a non-specific febrile illness. Infection of the nervous system may occur at all ages, but mostly affect infants, commonly as an aseptic meningitis and usually from coxsackievirus group B. Coxsackie encephalitis is an uncommon cause of encephalitis as all the enteroviruses account for $5 \%$ of all encephalitides. The clinical picture is similar to other viral encephalitis. Encephalitis may occur in all age groups with preference for children or young adults and is commonly seen in coxsackievirus types A9, B2, and B5. Acute flaccid paralysis, caused by infection of anterior horn cells in the spinal cord, may also be seen with coxsackievirus A7 infection [8].

In contrast to Guillian-Barre syndrome, viral infections preceding the development of MG are rare. A recent report of 6 cases of newly diagnosed MG diagnosed occurred 3-7 months after infection with West Nile virus (WNV) [7]. All of the patients had neuroinvasive infections including WNV anterior myelitis. The authors hypothesized that the viral pathogen triggered autoimmunity of the host. Another study reported of an autoantigenic site of the AChR alpha-subunit showing to have biologic activity and react immunochemically with herpes simplex virus, supporting the idea of neuroinvasive infection triggering autoimmune MG [9]. Several explanations of virus triggering host autoimmunity have been proposed; including, molecular mimicry, epitope spreading, bystander activation, cryptic antigen, and polyclonal activation [7,10]. Molecular mimicry, which is thought to be the main mechanism, occurs when the pathogen peptides share similar structure to host epitope activating immune cells that cross react with the host tissue $[11,12]$.

Our case is unique and represent the first report of a new onset MG following coxsackie encephalitis. Given the temporal relationship with 5 months delay of the initial MG symptoms, it is possible that this neuroinvasive infection induced host autoimmunity, leading to the development of MG. However, the fact that AChR antibodies could also have been present in the patients before the clinical symptoms of MG could not be totally excluded. Coxsackievirus itself is also notorious for triggering host autoimmune. Coxsackievirus B4 has a strong association with type 1 diabetes mellitus by similar mechanism of molecular mimicry leading to destruction of insulin-producing pancreatic cells [13]. Also, coxsackievirus B1 has been well recognized for its relationship with myocarditis [14].

Also, upon a thorough literature review, we found a number of neurological disorders occurring following viral infections (Table 1). Both central and peripheral neurological disorders were reported. The time between the initiation viral infections until the development of neurological disorders varied, ranging from 11 days to 7 months.

\begin{tabular}{|c|c|}
\hline $\begin{array}{c}\text { Preceding viral } \\
\text { infection }\end{array}$ & \begin{tabular}{c} 
Neurological disorders \\
\hline $\begin{array}{c}\text { Coxsackie virus } \\
\text { infection, Dengue } \\
\text { fever }\end{array}$
\end{tabular} \\
\hline Japanese encephalitis & $\begin{array}{c}\text { Acute transverse myelitis } \\
{[10,15]}\end{array}$ \\
\hline HSV infection & $\begin{array}{c}\text { Anti-N-Methyl- } \\
\text { D-Aspartate receptor } \\
\text { antibody encephalitis[16] }\end{array}$ \\
\hline
\end{tabular}




\begin{tabular}{|c|c|}
\hline $\begin{array}{l}\text { Preceding viral } \\
\text { infection }\end{array}$ & Neurological disorders \\
\hline Hepatitis E infection & $\begin{array}{c}\text { Neuralgic amyotrophy } \\
{[6]}\end{array}$ \\
\hline $\begin{array}{c}\text { West Nile } \\
\text { Poliomyelitis }\end{array}$ & MG [7] \\
\hline West Nile infection & $\begin{array}{l}\text { Stiff person syndrome } \\
{[17]}\end{array}$ \\
\hline $\begin{array}{c}\text { Zika virus, Epstein- } \\
\text { Barr Virus, Influenza } \\
\text { A, Hepatitis A, B and } \\
\text { E infection }\end{array}$ & $\begin{array}{c}\text { Guillain-Barre Syndrome } \\
{[18-21]}\end{array}$ \\
\hline
\end{tabular}

In summary, we report a patient with MG occurring 5 months after previous coxsackie encephalitis. Given the temporal relationship, we postulate that MG was the result of viral encephalitis triggering host autoimmunity. The cross-reactivity between Ach receptor antibody and anti-coxsackievirus antibody requires further investigation and to establish the causative association between coxsackie virus infection and MG needs a larger study with more patients.

\section{References}

1. Vadalà M, Poddighe D, Laurino C, Palmieri B (2017) Vaccination and autoimmune diseases: is prevention of adverse health effects on the horizon? EPMA J 8: 295-311.

2. Jones TB, Basso DM, Sodhi A, Pan JZ, Hart RP, et al. (2002) Pathological CNS autoimmune disease triggered by traumatic spinal cord injury: implications for autoimmune vaccine therapy. J Neurosci Off J Soc Neurosci 22: 2690-700.

3. Schoser B, Eymard B, Datt J, Mantegazza R (2017) Lambert-Eaton myasthenic syndrome (LEMS): a rare autoimmune presynaptic disorder often associated with cancer. J Neurol DOI: 10.1007/s00415-017-8541-9.

4. Kuwabara S, Yuki N (2013) Axonal Guillain-Barré syndrome: concepts and controversies. Lancet Neurol 12: 1180-8.

5. Niemeyer B, Niemeyer R, Borges R, Marchiori E (2017) Acute Disseminated Encephalomyelitis Following Zika Virus Infection. Eur Neurol 77: 45-6.

6. van Eijk JJJ, Madden RG, van der Eijk AA, Hunter JG, Reimerink JHJ, et al. (2014) Neuralgic amyotrophy and hepatitis E virus infection. Neurol 82: $498-503$.

7. Leis AA, Szatmary G, Ross MA, Stokic DS (2014) West nile virus infection and myasthenia gravis. Muscle Nerve 49: 26-9.

8. Fowlkes AL, Honarmand S, Glaser C, Yagi S, Schnurr D, et al. (2008) Enterovirus-associated encephalitis in the California encephalitis project, 1998-2005. J Infect Dis 198: 1685-91.

9. Schwimmbeck PL, Dyrberg T, Drachman DB, Oldstone MB (1989) Molecular mimicry and myasthenia gravis. An autoantigenic site of the acetylcholine receptor alpha-subunit that has biologic activity and reacts immunochemically with herpes simplex virus. J Clin Invest 84: 1174-80.

10. Okada H, Wada M, Sato H, Yamaguchi Y, Tanji H, et al. (2013) Neuromyelitis optica preceded by hyperCKemia and a possible association with coxsackie virus group A10 infection. Intern Med Tokyo Jpn 52: 2665-8.

11. Ercolini AM, Miller SD (2009) The role of infections in autoimmune disease. Clin Exp Immunol 155: 1-15.

12. Wucherpfennig KW (2001) Mechanisms for the induction of autoimmunity by infectious agents. J Clin Invest 108: 1097-104.

13. Hyöty H (2002) Enterovirus infections and type 1 diabetes. Ann Med 34: 138-47.

14. Tschöpe C, Müller I, Xia Y, Savvatis K, Pappritz K, et al. (2017) NOD2 (Nucleotide-Binding Oligomerization Domain 2) Is a Major Pathogenic Mediator of Coxsackievirus B3-Induced Myocarditis. Circ Heart Fail 10: pii: e003870.

15. Verma R, Praharaj HN, Patil TB, Giri P (2012) Acute transverse myelitis following Japanese encephalitis viral infection: an uncommon complication of a common disease. BMJ Case Rep pii: bcr2012007094.

16. Desena A, Graves D, Warnack W, Greenberg BM (2014) Herpes simplex encephalitis as a potential cause of anti-N-methyl-D-aspartate receptor antibody encephalitis: report of 2 cases. JAMA Neurol 71: 344-6.

17. Hassin-Baer S, Kirson ED, Shulman L, Buchman AS, Bin H, et al. (2004) Stiff-person syndrome following West Nile fever. Arch Neurol 61: 938-41.

18. Medina MT, Medina-Montoya M (2017) New spectrum of the neurologic consequences of Zika. J Neurol Sci pii: S0022-510X(17) 34426-X.

19. Jacobs BC, Rothbarth PH, van der Meché FG, Herbrink P, Schmitz PI, et al. (1998) The spectrum of antecedent infections in Guillain-Barré syndrome: a case-control study. Neurology 51: 1110-5.

20. Parra B, Lizarazo J, Jiménez-Arango JA, Zea-Vera AF, González-Manrique G, et al. (2016) Guillain-Barré Syndrome Associated with Zika Virus Infection in Colombia. N Engl J Med 375: 1513-23.

21. Wijdicks EFM, Klein CJ (2017) Guillain-Barré Syndrome. Mayo Clin Proc 92: 467-79. 